\title{
Micro Hydro Power: A Source of Sustainable Energy in Rural Communities: Economic and Environmental Perspectives
}

\author{
MOHAMMAD UMAR and ANWAR HUSSAIN
}

\section{INTRODUCTION}

Energy is an important need of human life. It is the life blood of all economic activities. Due to increase in population and economic activities, the need for energy is increasing at a faster rate. Without having sufficient energy, the goal of economic and social development and the Millennium Development Goals in particular cannot be achieved.

Most of the rural areas in different parts of the world are without electricity. About 1.6 billion people in the world who are living in rural areas are without electricity [Greenstone (2014)]. The reason is that it is too costly to provide electricity services to rural communities through conventional means due to remote location and low density of population. Moreover, due to poverty and low income the rural inhabitants are not in a position to afford the main grid electricity. The use of diesel and gasoline has been used for decades for provision of electricity to rural areas. But it was not so successful due to economic, technical and environmental problems [Woodruff (2007a)].

Given this backdrop, Pakistan is being faced with the electricity shortages for the last several years. There are many factors that have intensified this issue. High cost with low level of energy generation as compared to demand being manifold the supply. While the country's growing population and economic activities necessitate the generation of more energy. On the other hand, there are also issues of conservation, misuse and overuse of energy at household and industrial level. Line losses, electricity theft, corruption, mismanagement and lack of political consensus on the big power projects are other factors that have significantly contributed to the energy crisis in Pakistan [Pakistan (2013)].

In the wake of the issue of climate change and environmental degradation, the importance of clean energy technologies has been increasing. In 2004 about US\$55 billion was invested in renewable energy in the world, which is just one third of the amounts that was invested in conventional power plants. In 2005, renewable energy supplied 17 percent of the world primary energy. This growth in renewable energy

Mohammad Umar <Umarsafi452@gmail.com> is Assistant Professor (Economics), Government Post Graduate College Khar Bajaur (FATA), KPK. Anwar Hussain <anwar@pide.org.pk> is Assistant Professor at the Pakistan Institute of Development Economics, Islamabad. 
occurred in developing countries, which accounts for 44 percent of the world renewable generating capacity [Woodruff (2007b)].

The renewable energy technologies are highly expected to grow in the future due to declining prices, and the need for environmental protection [Paish (2002)]. The renewable energy sources include hydropower, solar energy, wind, biomass and geothermal energy etc. The energy or electricity generated from these sources is clean. It means that it causes no GHG emissions.

Hydro power is the largest source of renewable energy. Sixteen percent of electric energy in the world is generated from hydro power. Its share in the renewable energy is about four-fifths in the world [Dolf (2012)]. More than 1200MW micro/mini hydro power potential is estimated to be available in the country. Out of this potential, less than 5 percent is being developed. For microhydel power plants with capacities 100 and $500 \mathrm{KW}$ each, an estimated potential of 300MW and more than 400MW, respectively exists in Northern Area only [Sheikh (2010)].

Hydro power is classified on the basis of its size and energy generation capacity. This classification has been made for European countries. Large hydro project has a generation capacity of $100 \mathrm{MW}$. While medium-hydro project has a generation capacity of 20MW-100MW. Small-hydro project has a capacity of 1MW to 20MW. Mini-hydro project ranges from $100 \mathrm{KW}$ to $1 \mathrm{MW}$. This may be a stand alone or grid connected. Micro-hydro project has a capacity of $5 \mathrm{KW}$ to $100 \mathrm{KW}$ that supplies electricity to a small community in rural areas [Dolf (2012)].

Micro Hydro Power (MHP) ${ }^{1}$ can be an option for providing a reliable and cheap energy to the rural communities. This technology has the advantage that it can be made on small streams, canals and river tributaries in the hilly areas. This technology does not require the storage of water or building a reservoir or dam. Water is only diverted from a river through a power channel towards a power house. The water that is used to run a turbine can again meet the same river without any loss. It requires no combustion of fuel or gas. This system is cost effective as compared to solar and wind energy [Dolf (2012)]. Because sun light varies with respect to time and place. It is only available during the day. Similarly, wind power also depends on location and speed of wind which varies from time to time.

The area that is taken as a case study is district Dir (upper) Khyber Pakhtunkhwa, where different MHP plants are operating in the area to provide electricity to the local population. Some of the plants are installed by Government organisations and some are installed by community itself. River Panjkora (river of five tributaries) is flowing in the area. The river as well as its tributaries offer a number of sites for small and Micro hydro power plants.

The existing studies on micro hydro power [e.g. Woodruff (2007b); Edvard (2011); Hanggoro (1998); Sarala (2009)] conducted the Cost Benefit Analysis (CBA) of Micro hydro power projects. The authors have used NPV and IRR as evaluation criteria for MHP projects. Arthur and Stephen (2006), has given the impact of micro hydro power projects on the rural population in terms of increased income through productive

${ }^{1}$ Micro Hydro Power is a technology for generating electricity on small streams and canals that require no dam or storage of water. It is also called as run of the river technologies. Its generating capacity ranges from $5 \mathrm{Kw}$ to $100 \mathrm{Kw}$ [Khennas and Barnett (2000)]. 
activities, employment creation, increase in working hours during night and increase in study hours for students. The methodology used to collect information was participatory rural appraisal tools, stakeholder analysis and Focused Group Discussion. Household survey, Transect Walks and household interviews were also used to collect data. A study [Condrea and Bostan (2008)] has discussed the sustainable management of Micro hydro power. It has identified different issues and explored lessons learned from the MHP projects. The study suggested that the experience and lessons learned from the existing projects should be taken into account while deciding the introduction of MHP projects in future. Dorji (2007) assessed the sustainable management of Micro hydro power. The study objective was to investigate the institutional mechanism that will ensure equitable, economically efficient and sustainable Micro hydro power for rural communities of Bhutan. Semi-structured interviews and key informant survey techniques are used for the study. Financial analysis of the study shows that revenue from the current tariff does not meet the combined cost of annual operation and maintenance. The development of MHP should be coupled with the development of income generating opportunities to increase the self- reliance of rural communities. The author estimated that the project was expected to generate about $580,000 \mathrm{kWh}$ of energy annually and reduce 500 tones of $\mathrm{CO}_{2}$ equivalent per year. The study further estimated that only 36 percent of the net generation is being utilised accounting for an estimated 12 percent distribution loss. However, these estimations depend on the site location, cultural and institutional environment in which they are operating. Mirza, et al. (2009) ${ }^{2}$ identified the policy barriers to promotion of community based renewable energy technologies in Pakistan. These barriers are policy barriers, institutional barriers, fiscal and financial barriers, technological and social barriers. Only a few studies [e.g. Purohit (2008) and Shakya (2005) in India and Nepal] have assessed the environmental benefits of Micro hydro power (MHP) in the form of GHG emission reductions and CDM. Purohit (2008) estimated the gross potential of Small Hydro Power (SHP) as $15 \mathrm{GW}$ in India with the annual Certified Emission Reductions (CER) potential of 24 million tones of $\mathrm{CO}_{2}$ equivalent.

While in Pakistan, a little work is done on Micro hydro power. Therefore, the present study attempts to fill this gap and estimate the emission reductions that would have occurred in the absence of MHP plants/ projects.

Basic objectives of the study are (1) to show the role of Micro hydro power in generating electricity for rural communities in District Dir (upper), Khyber Pakhtunkhwa, (2) to assess the cost effectiveness and environmental sustainability of Micro hydro power and (3) to identify the issues and problems associated with Micro hydro power in rural areas.

The remainder of the study is organised as follows. Section 2 discusses the data and methodology of the study. Section 3 explains results and discussion while the final section concludes the study along with policy implications.

\section{DATA AND METHODOLOGY}

The study uses the primary data taken from the households of District Dir (Upper) Khyber Pakhtunkhwa, Pakistan. This study covers 100 main grid (WAPDA) connected

${ }^{2}$ Mirza, Ahmad, Harijan, and Majeed (2009). 
households and 100 MHP connected households. Two separate questionnaires were designed for each category of households. This was done to capture the difference in the energy patterns, the difference in the expenditure made on energy between the two types of households and the relative cost of MHP and WAPDA electricity to the households. There are 2867 WAPDA connected households and 2160 MHP connected households in the sampled area. A sample size of 100 households is selected from each category. The sample size was calculated through sample size calculator. We have also taken the 35 MHP plants as a sample to get the relevant information. Qualitative data was taken through informal survey.

This study uses descriptive analysis to capture the socio-economic aspect of the households, their expenditure on energy items, and use of alternative sources of energy. Financial and Economic analysis is undertaken, which includes the estimation of Benefit Cost Ratio (BCR), Net Present Value (NPV), Internal Rate of Return (IRR) and Pay Back Period (PBP) of the Micro hydro power project using a discount rate of 12 percent. Per unit energy price of WAPDA and MHP electricity is also calculated using the electricity bills of the households. WAPDA connected households have proper metering system and receive bills along with the total units consumed. But the MHP plants have no metering system. The households pay a fixed flat tariff to the owner of the power plant regardless of how much electricity is consumed. Therefore, to arrive at per unit price of MHP electricity, we divide the total monthly bill on the total units consumed by the household (assuming an average consumption of $5 \mathrm{kWh}$ per day).

Environmental analysis is also undertaken to arrive at the total emissions reductions from the MHP power plants. For this purpose we use energy baseline. Energy baseline is the fuel consumption of the technology that would have been used in the absence of project activity. The emission baseline is calculated using the aggregate of annual $\mathrm{kWh}$ output of all the MHP plants times the $\mathrm{CO}_{2}$ emission factor for the fuel displaced [Pandey (2008)]. $\begin{array}{ccccccc}\text { Annual power generation }(\mathrm{kWh} / \mathrm{year})^{3} & = \\ \text { Factor } & \text { Plant Capacity } & (\mathrm{kW}) * \text { Plant Capacity } \\ \text { Fours }^{4} & \ldots & \ldots & \ldots & \ldots & \ldots & \ldots\end{array}$

Annual $\mathrm{CO}_{2}$ emission reductions (tones of $\mathrm{CO}_{2} \mathrm{eq}$ ) $=$ Power generation $\left(\mathrm{kWh} /\right.$ year) $*$ Emission Factor (tones of $\mathrm{CO}_{2} / \mathrm{kWh}$ )

Emission reductions from CDM projects in the power sector can be calculated based on the net electricity generated by the project and the difference between the emissions $\left(\mathrm{CO}_{2} / \mathrm{kWh}\right)$ of the baseline and the project activity [Akella, et al. (2009)].

$$
\begin{aligned}
& \begin{array}{lllllll}
\mathrm{E}_{\text {reductions }}=\mathrm{E}_{\mathrm{B}}-\mathrm{E}_{\text {Project }} & \ldots & \ldots & \ldots & \ldots & \ldots & \ldots
\end{array} \\
& \mathrm{E}_{\text {reductions }}=\text { Emission reductions } \\
& \mathrm{E}_{\mathrm{B}}=\text { Baseline Emissions } \\
& \mathrm{E}_{\text {Project }}=\text { Project Emissions }
\end{aligned}
$$

\footnotetext{
${ }^{3}$ As there is no metering system and no proper book keeping of the per day electricity generation (in $\mathrm{kWh}$ ) of the power plants in the study area, the annual electricity generation is estimated by simply aggregating the installed capacity of each MHP plant in hours.

${ }^{4}$ Plant Capacity Factor or load factor= Average Demand/ Installed Capacity [Akella, Saini, and Sharma (2009)].
} 
As emissions from Micro hydro power plants construction is negligible or zero, therefore, emission reductions are equal to base line emissions $\left(\mathrm{E}_{\mathrm{B}}\right)$. Moreover, MHP do not require the storage of water or dam and projects with less than $5 \mathrm{MW}$ capacities required no Environmental Impact Assessment (EIA).

Total annual emission reductions can be calculated by multiplying $E_{B}$ by the emission factor of the fuel displaced. An emission factor of $1.83^{5} \mathrm{~kg} \mathrm{CO}_{2} \mathrm{eq} / \mathrm{kWh}$ is used for the analysis.

Baseline Emissions $\left(\mathrm{tCO}_{2} / \mathrm{yr}\right)=\mathrm{E}_{\mathrm{B}}(\mathrm{kWh}) * 1.83 \mathrm{~kg} \mathrm{CO} \mathrm{CO}_{2} \mathrm{eq} / \mathrm{kWh} * 1 / 1000=\mathrm{tCO}_{2} \mathrm{eq}$

The qualitative analysis has been done by using informal survey techniques such as focused group discussion and key informant survey etc. The informal survey techniques are also called as Participatory Rural Appraisal (PRA). Informal survey may be used as a supplement to the quantitative survey. Evidence shows that this type of survey is more reliable and valid as compared with data collected through other traditional methods [Kumar (1989)]

For this study we have arranged four focused groups. Each focused group consists of six to eight members taken from the community. The members had different socio economic backgrounds. The prospects and issues of MHP's were thoroughly discussed with the members of focused groups. Main findings were noted to reach conclusion.

Key informant survey is a loosely structured conversation with people who have specialised knowledge about the topic you wish to understand. This type of interview consists of open ended questions. I took a school teacher of village Tarpatar, ex-nazim of union council Jabar and health workers of rural health centre Tarpatar as key informants. Basic information of MHP plants and the issues associated with MHP were discussed.

\section{RESULTS AND DISCUSSION}

This section presents the results of descriptive analysis of important variables used in the study. It also gives the comparative cost analysis of MHP's and WAPDA electricity. Financial and Economic analysis followed by Environmental analysis (estimation of emission reductions) are also part of this section.

\subsection{Descriptive Analysis}

Table 1 in Appendix gives the detail of Micro hydro power plants operating at Ushairy in the upper Dir district. These plants are mainly run by private sector. The total installed capacity of the $35 \mathrm{MHP}$ plants is $1058 \mathrm{~kW}$ or $1.058 \mathrm{MW}$. The MHP units installed by government have a more capacity than the MHP's installed by the community. The reason is that they are installed with proper specification. While the community based units are installed through simple methods because of lack of funds and the required skills.

${ }^{5}$ Emission factor of $1.83 \mathrm{kgCO}_{2}$ eq $/ \mathrm{kWh}$ is based on a survey conducted in Gilgit, Chitral, and Baltistan. This is taken from the diesel generators sets that are being used in the area. For further detail see CDM, Project Design Document (PDD) Form Version 03, Community based Renewable Energy Development in Northern Areas and Chitral, Pakistan [Pandey (2008)]. 
Table 1

Classification of MHP and Non-MHP Users with Respect to their Sources of Lighting

\begin{tabular}{lcccccc}
\hline & \multicolumn{5}{c}{ Sources of Lighting } \\
\cline { 2 - 6 } Type of Users & WAPDA & Kerosene Oil & Solar Cells & Generators & DC Lamps \\
\hline Non-MHP (WAPDA) Users in $\%$ & 7 & 19 & 2 & 10 & 62 & 0 \\
MHP Users in \% & 0 & 2 & 0 & 0 & 13 & 85 \\
\hline
\end{tabular}

Source: Field Survey.

\subsubsection{Main Source of Lighting}

As the duration of light in the households of users of hydro power is greater than the duration of light from WAPDA electricity, therefore non users uses other alternatives like kerosene oil, LPG and DC chargeable lamps to meet their needs. Majority of MHP users responded that their main source of lighting is MHP while the non-MHP users use DC chargeable lamps as the main source of lighting.

Table 1 shows the main source of lighting for MHP and non-MHP households. This is 62 percent of all other sources of light. On the other hand, the main source of lighting in the households connected with Micro hydro power is the electricity supplied by these MHP power plants. In other words 85 percent of households stated MHP as the main source of lighting. While the main grid electricity, kerosene oil and DC chargeable lights have 4 percent, 2 percent and 9 percent share in the source of lighting respectively. Moreover, the WAPDA connected households use DC chargeable lights as an alternative source of lighting. Households that use Kerosene oil is only 2 percent in case of MHP, while 19 percent of WAPDA connected households use kerosene oil. The consumption of kerosene oil is also higher in WAPDA connected households as compared to the MHP households.

\subsubsection{Daily Availability of Electricity}

The Table 2 below shows the electricity or the availability of light for both categories of households. The duration of light available to households using WAPDA electricity is 2-3 hours daily. While the duration of light available to the households using electricity from MHP is $8-12$ hours daily. It means that about 20 hours load shedding is faced by non-MHP users.

Table 2

Daily Availability of Electricity

\begin{tabular}{lcc}
\hline Type of Users & Availability of Light & Household Response in \% \\
\hline Non-MHP Users (WAPDA) & $2-3$ hours & 95 \\
& $4-5$ hours & 5 \\
\multirow{2}{*}{ MHP } & $8-12$ hours & 90 \\
& $13-17$ hours & 10 \\
\hline
\end{tabular}

Source: Field Survey. 


\subsubsection{Monthly Electricity Bill and Connection Charges}

The data in Table 3 shows a comparison of average monthly electricity bill and connection costs that household pay for using WAPDA electricity and electricity from MHP. Both types of households are significantly different with respect to their monthly payment and connection costs. The minimum and maximum bill households pay for WAPDA electricity are Rs 500 and Rs 3000 per month, respectively. On the other hand, the minimum and maximum bill that households pay for MHP is Rs 100 and Rs 400 per month respectively. The users of MHP pay a fixed sum of money to the operator or owner of the plant per month. The average connection charges of WAPDA electricity is Rs 6500, while that of MHP it is Rs 4000. In case of MHP, the users take their own connection from the power plant. The cost of wire depends on the distance between the plant and the household. The greater the distance the greater the connection cost. This analysis concludes that the use of electricity from MHP is cheaper than the WAPDA electricity in terms of monthly payment and connection costs.

Table 3

Monthly Electricity Bill and Connection Charges

\begin{tabular}{lccccccc}
\hline \multirow{2}{*}{ Type of Users } & \multicolumn{3}{c}{ Monthly Bill (Rs) } & & \multicolumn{3}{c}{ Connection Charges (Rs) } \\
\cline { 2 - 4 } & Min & Max & Mean & & Min & Max & Mean \\
\hline WAPDA Connected & 500 & 3000 & 920 & & 5000 & 7000 & 6500 \\
MHP Connected & 100 & 400 & 200 & & 1000 & 7000 & 4000 \\
\hline Source: Field Survey & & & & & & &
\end{tabular}

\subsubsection{Comparison of Fuel Wood and other Sources of Energy Used}

This part of the analysis shows the amount of fuel wood and other energy sources used by MHP users and non-MHP users (Table 4). This analysis also estimates the difference in consumption of energy items and their associated cost of the two categories of households. As kerosene oil, LPG, Diesels and DC chargeable lights are used in greater quantities in non-MHP households; therefore the cost of using these items are also greater than the cost in the case of MHP households.

Table 4

\begin{tabular}{|c|c|c|c|c|c|c|c|}
\hline \multirow[b]{2}{*}{ Energy Sources } & \multirow[b]{2}{*}{ Unit } & \multicolumn{3}{|c|}{ Non-users of MHP(WAPDA) } & \multicolumn{3}{|c|}{ MHP Users } \\
\hline & & Min & Max & Mean & $\overline{\text { Min }}$ & $\operatorname{Max}$ & Mean \\
\hline Quantity of fuel wood used per month & Maund & 2 & 30 & 10 & 5 & 10 & 11 \\
\hline Monthly expenditure on fuel wood & Rs & 800 & 20000 & 4650 & 1000 & 8000 & 4675 \\
\hline Monthly expenditure on kerosene oil & Rs & 120 & 2000 & 525 & 240 & 500 & 350 \\
\hline Monthly expenditure on LPG & Rs & 500 & 2700 & 1462 & 300 & 3000 & 1000 \\
\hline $\begin{array}{l}\text { Monthly expenditure on others (DC lights, } \\
\text { UPS, Diesels etc.) }\end{array}$ & Rs & 300 & 7000 & 1750 & 100 & 4150 & 532 \\
\hline
\end{tabular}


In the above analysis it is clear that the monthly expenditure of MHP households on energy is lower than the expenditure made by non- MHP households. Because the excessive load shedding from WAPDA compel people to shift their preferences to other alternatives. They use Liquefied Petroleum Gas (LPG), Diesel generators, Kerosene oil and DC chargeable lights for lighting and other purposes. This leads to an increase in expenditure on energy. On the other hand the MHP users use electricity for 8 to 12 hours per day and pay a nominal bill per month to the owner of the power plant. Thus, it is cost effective and economical for the households to use electricity of MHP instead of WAPDA electricity.

\subsubsection{Degree of Satisfaction with Availability of Electricity}

Majority of the respondents were not satisfied with the availability of WAPDA electricity. However, they were satisfied with the electricity available from MHP plants. The percentages of the respondents who are satisfied or otherwise are given in the Table 5 below.

Table 5

Degree of Satisfaction from Availability of Electricity

\begin{tabular}{lccccc}
\hline & \multicolumn{5}{c}{ Satisfaction Categories } \\
\cline { 2 - 6 } Type of Users & Highly Satisfied & Satisfied & Neutral & Dissatisfied & Highly Dissatisfied \\
\hline MHP Users (\%) & 25 & 60 & 4 & 11 & 0 \\
WAPDA Users (\%) & 0 & 12 & 2 & 56 & 30 \\
\hline
\end{tabular}

\subsection{Comparative Cost Analysis of MHP and WAPDA Electricity}

\subsubsection{Cost of Electricity Generated from Micro Hydro Power (MHP) Plant}

In this section we estimate the relative unit capital cost (Rs $/ \mathrm{kW})$ and the unit energy price (Rs $/ \mathrm{kWh}$ ) of the Micro hydro power plant.

The average MHP plant size/ capacity $=30 \mathrm{~kW}^{6}$

Unit capital cost or installed capital cost $=400000 / 30=$ Rs $13333 / \mathrm{kW}$

$1 \mathrm{kWh}=1$ unit of energy

The MHP plant operates for 10 hours on average per day. Therefore, the total energy generation per day will be $30 \mathrm{~kW} * 10$ hours $=300 \mathrm{kWh}$.

Assume that average household consumption $=5 \mathrm{kWh}$ per day.

Per month consumption $=5 \mathrm{kWh} * 30=150 \mathrm{kWh}$

The average bill that the consumers pay for using MHP electricity = Rs 200/ month, therefore the electricity price per unit $=200 / 150 \mathrm{kWh}=\mathrm{Rs} 1.33 / \mathrm{kWh}$

\subsubsection{Cost of Electricity Generated from WAPDA}

Per unit cost of WAPDA electricity in Pakistan is Rs 12. It is Rs 23/unit for High Speed Diesel [Pakistan (2013)].

${ }^{6}$ The average plant size or capacity is derived from the total capacity of 35 surveyed MHP plants in the area, which is $1058 \mathrm{~kW}$ i.e. $1058 / 35=30 \mathrm{~kW}$. 
The tariff rate is Rs 9 per unit for consumers whose consumption is in the range of 101- 200 units. For commercial consumers the rate is Rs 18/unit [IESCO (2013)].

Hydro power in the total energy mix in Pakistan is 35 percent. Furnace oil based is 34 percent of the total power supplies. The fuel cost of this energy generation is Rs 14.76 per unit. The gas based power generation is 25 percent. The diesel power generation cost is Rs 15.63 per unit. The average fuel cost of the power generation is Rs 6.07 per unit [Pakistan (2013)].

1 unit $=1 \mathrm{kWh}$

Price per unit of WAPDA electricity for consumers using 100kWh to $200 \mathrm{kWh}$ equals Rs 9. Assume that per day consumption of a typical household is $5 \mathrm{kWh}$. Then, the monthly bill will be $150 * 9=$ Rs 1350 .

Table 6

Electricity Price per Unit (in Rs)

\begin{tabular}{lccc}
\hline & Household Energy & Per Month & Electricity Price per \\
& Consumption in kWh/Day & Consumption & Unit in Rs \\
\hline MHP Electricity & $5 \mathrm{kWh}$ & $150 \mathrm{kWh}$ & 1.33 \\
WAPDA Electricity & $5 \mathrm{kWh}$ & $150 \mathrm{kWh}$ & 9 \\
Difference & - & - & 7.67 \\
\hline
\end{tabular}

\subsection{Financial and Economic Analysis of MHP}

The results of Financial and Economic Analysis are given in this section. Initial capital cost of MHP is Rs 402000. The life of the MHP projects ranges from 20 years to 35 years. But we have taken the life of the project as 25 years on average. Completion time for the project is one year. In case of MHP, the Financial Internal Rate of Return (FIRR) is 24 percent, which is greater than the discount rate of 12 percent. On the other hand, the Economic Internal Rate of Return (EIRR) is 27 percent and is greater than the FIRR. The reason is that the financial return takes into account only the benefits or return to the investor and does not take into account other benefits (tangible and intangible) to the whole society or the economy. In Economic analysis the benefits that accrue to the society increase through the multiplier effect. As both the FIRR and ERR are greater than the discount rate, therefore the project is acceptable from both investor and society's point of view.

The Financial NPV is 350, which is greater than zero. The Economic NPV is 459, which is also positive and hence the project is feasible and worth to undertake. The BCR in financial analysis is 1.25 and in the Economic analysis, it is 1.26 , both are greater than one. Therefore, we can conclude that according to this criterion, the Micro hydro power project is viable and worthy to be undertaken.

In Financial Analysis, the Pay Back Period (PBP) is five years. While in Economic Analysis, the Pay Back Period is 3.6 years. The PBP of Financial analysis is more than the PBP in Economic analysis. The reason is that there are more returns from MHP projects due to its impact on the education, health and other economic and social activities through the multiplier effect. Detail of Financial and Economic analysis is given in Table 2 and Table 3 in Appendix. 
The Table 7 shows the result of sensitivity analysis when capital cost is increased by 10 percent.

Table 7

Sensitivity Analysis with 10 Percent Increase in Capital Cost

\begin{tabular}{lcc}
\hline Description & Financial Analysis & Economic Analysis \\
\hline IRR & $22 \%$ & $23.10 \%$ \\
NPV & 317.7 & 315.6 \\
BCR & 1.22 & 1.40 \\
PBP & 5 Years & 5 years \\
\hline
\end{tabular}

\subsection{Emission Reductions through MHP}

As there is low access to national electricity grid due to remoteness and the difficult topography, there is more probability of using diesel generators by the local population. This practice will lead to more use of costly fuels. This will not only lead to more expenditure on fossil fuels but also cause Green House Gas (GHG) emissions. Therefore, the existing MHP plants and expected new power plants will reduce the green house gas emissions that would otherwise be produced from the use of diesel based generators.

The total installed capacity of the $35 \mathrm{MHP}$ plants is $1058 \mathrm{KW}$, which is equal to $1.058 \mathrm{MW}$. From the household survey, we found that each MHP plant operates from 812 hours. Therefore, we take 10 hours as average operating time per day. This gives us electricity generation in $\mathrm{kWh}$ per day.

Annual power generation $(\mathrm{kWh})=$ Plant Capacity $(\mathrm{kW}) *$ Plant Capacity Factor* hours

Annual power generation $(\mathrm{kWh})=1058(\mathrm{~kW}) * 0.45^{7} * 3650$ hours

$$
\begin{aligned}
& =3861700 \mathrm{kWh}^{*} 0.45 \\
& =1737765 \mathrm{kWh}
\end{aligned}
$$

Multiplying by the emission factor of $1.38 \mathrm{~kg} \mathrm{CO}_{2} \mathrm{eq} / \mathrm{kWh}$, we get total baseline emissions.

Annual Baseline Emissions $\left(\mathrm{tCO}_{2}\right)=1737765 \mathrm{kWh} * 1.38 \mathrm{~kg} \mathrm{CO} 2 \mathrm{eq} / \mathrm{kWh} / 1000=$ 3180 tones $\mathrm{CO}_{2} \mathrm{eq} /$ annum.

Emissions from Micro hydro power plants construction are negligible or zero and MHP do not require the storage of water or dam. Moreover, projects with less than $5 \mathrm{MW}$ capacities require no Environmental Impact Assessment (EIA). Therefore, emission reductions are equal to base line emissions $\left(\mathrm{E}_{\mathrm{B}}\right)$.

$$
\mathrm{E}_{\text {reductions }}=\mathrm{E}_{\mathrm{B}}-\mathrm{E}_{\text {Project }}
$$

$\mathrm{E}_{\text {reductions }}=\mathrm{E}_{\mathrm{B}}-0=\mathrm{E}_{\mathrm{B}}=\mathbf{3 1 8 0}$ tones $\mathrm{CO}_{\mathbf{2}} \mathbf{e q} /$ annum. This value is the estimated emissions that are reduced by the MHP plants.

${ }^{7}$ The installed Micro hydro power plants are expected to have an average load factor or capacity factor of 0.45 . This also includes 2 percent of down time for the system for repairs. The demand for electricity reaches to the capacity of the power plant during evening peak hours [Pandey (2008)]. 


\subsubsection{Benefits of Micro Hydro Power Technologies through CDM}

Pakistan signed the United Nations Framework Conventions on Climate Change (UNFCCC) in 1992. Thus it qualifies to take benefits from market based flexible mechanism under the convention for addressing the issue of climate change. One of the mechanism is called Clean Development Mechanism (CDM) [Nizami and Bukhari (2010)].

Pakistan is a "Non- Annex 1"country. ${ }^{8}$ It ratified the UNFCCC in 1994 on voluntary basis. Kyoto protocol of the UNFCCC is dealing with climate change mitigation. It is a milestone towards global carbon mitigation efforts [Ahmad and Salman (2012)].

The protocol led to the establishment of carbon markets through Clean Development Mechanism (CDM). Pakistan ratified the Kyoto Protocol in January 2005, and thus became eligible to benefit from CDM. While the CDM is a great opportunity for Pakistan, the country has not yet optimally utilised this mechanism to get financial benefits through selling Certified Emission Reductions (CERs). This may be due to the lack of knowledge and capacity building of the concerned ministry and investors in Pakistan. Therefore to get full benefits we have to initiate renewable energy projects as micro hydro power. This will on the one hand provide the needed energy to the rural population and on the other hand earn revenue through CDM by reducing green house gas emissions. Taking the current price of one tone of $\mathrm{CO} 2 \mathrm{eq}$ as $\$ 23,{ }^{9}$ if the given project of all the MHP's is registered with CDM, it will earn $\$ 95400$ per annum.

\section{CONCLUSION AND POLICY IMPLICATIONS}

The study attempted to find out the cost effectiveness, economic and financial viability and environmental sustainability of Micro hydro power plants in district Dir (upper), Khyber Pakhtunkhwa. The study is based on the primary data collected through questionnaires. The study is important because it carried out the financial and economic analysis and environmental analysis of Micro hydro power for the first time in Pakistan. To find out the viability of the MHP projects NPV, IRR, BCR and Pay Back Period are used and all these favoured the project under consideration. Monthly expenditure on kerosene oil is Rs 525 for WAPDA connected households while it is only Rs 350 for MHP connected households. Monthly expenditure on LPG is Rs 1462 for WAPDA and Rs 1000 for MHP connected households. Moreover, monthly expenditure on alternative sources of energy is Rs 1750 for WAPDA and Rs 532 for MHP connected households. It is estimated that the electricity provided by MHP to the households is cheaper than the electricity of WAPDA. This technology replaces the electricity generated by fuel based generators. The estimated emission reduction from MHP project is 3180 tones $\mathrm{CO}_{2} \mathrm{eq}$ per annum. These emission reductions can be traded through carbon markets by CDM to earn revenue. MHP plants have no adverse environmental impacts like, sedimentation, water logging, disturbance of ecosystem and habitat of animals and plants. The relevant issues

\footnotetext{
${ }^{8}$ Non-Annex 1 countries are mostly developing countries. These countries are not listed in Annex 1 to the UNFCCC. Certain developing countries are recognized by the convention as being more vulnerable to the adverse impact of climate change. Therefore, these countries are eligible to be the host parties for CDM projects. In other words they are not bound to reduce their emissions of GHG gases [UNFCCC (n.d.)].

${ }^{9}$ This is the price of 1 tones of $\mathrm{CO}_{2}$ equivalent used in CDM projects [Sharon and Angela (2012)].
} 
of finance, capacity building, training and other social issues (detail of issues is given in Table 5 in Appendix) need to be addressed so that the given projects may become a success story in the future. Based on these results and the highest potential of small and micro hydro power that exist especially in northern areas and KPK, it is suggested that the government should adopt the policy of small hydro power development. This will not only provide the much needed energy to the rural population but will also contribute to environmental protection.

\section{APPENDIX}

Table 1

\begin{tabular}{|c|c|c|c|c|c|c|c|c|}
\hline \multirow[b]{2}{*}{ S\# } & \multirow[b]{2}{*}{$\begin{array}{c}\text { Name of } \\
\text { Village }\end{array}$} & \multicolumn{3}{|c|}{ No of MHP's } & \multirow{2}{*}{$\begin{array}{c}\text { Total Electricity } \\
\text { Generation } \\
\text { Capacity (KW) } \\
\end{array}$} & \multirow[b]{2}{*}{$\begin{array}{c}\text { Year of } \\
\text { Installation } \\
\end{array}$} & \multirow[b]{2}{*}{$\begin{array}{c}\text { Organisation Who } \\
\text { Installed }\end{array}$} & \multirow{2}{*}{$\begin{array}{c}\begin{array}{c}\text { No of } \\
\text { Beneficiaries } \\
\text { (HH) }\end{array} \\
\end{array}$} \\
\hline & & $\overline{\text { Govt/NGO }}$ & Private & $\overline{\text { Total }}$ & & & & \\
\hline 1 & Samkote & 1 & 2 & 3 & 100 & 2009 & SRSP & 180 \\
\hline 2 & Batal & 1 & 2 & 3 & 100 & 2008 & SRSP & 160 \\
\hline 3 & Nashnamal & 1 & 1 & 2 & 80 & 2009 & UNICEF & 140 \\
\hline 4 & Danele & - & 2 & 2 & 50 & 2007 & Community & 70 \\
\hline 5 & Gur koi & 2 & - & 2 & 70 & 2009 & UNICEF & 100 \\
\hline 6 & Shomai & 1 & 1 & 2 & 80 & 2009 & UNICEF & 150 \\
\hline 7 & Jabai & & 2 & 2 & 40 & 2008 & Community & 90 \\
\hline 8 & Usharai Proper & 1 & - & 1 & 48 & 2013 & $\operatorname{ACTED}(J a p a n$ funded $)$ & 110 \\
\hline 9 & Usharai & - & 1 & 1 & 30 & 2010 & Private & 60 \\
\hline 10 & Usharai & - & 1 & 1 & 25 & 2010 & Private & 70 \\
\hline 11 & Tarpatar & 1 & - & 1 & 40 & 2012 & RAHA & 120 \\
\hline 12 & Amrete & - & 1 & 1 & 20 & 2009 & Community & 50 \\
\hline 13 & Amrete & - & 1 & 1 & 20 & 2008 & Community & 40 \\
\hline 14 & Amrete & - & 1 & 1 & 20 & 2008 & Community & 50 \\
\hline 15 & Amrete & - & 1 & 1 & 20 & 2009 & Community & 50 \\
\hline 16 & Amrete & - & 1 & 1 & 20 & 2009 & Community & 55 \\
\hline 17 & Amrete & 1 & - & 1 & 20 & 2009 & SRSP & 60 \\
\hline 18 & Barkand & - & 1 & 1 & 60 & 2007 & Community & 200 \\
\hline 19 & Almas & 1 & 2 & 3 & 90 & 2011 & MNA Funds & 170 \\
\hline 20 & Choran & - & 1 & 1 & 15 & 2008 & Private & 25 \\
\hline 21 & Kalkote & - & 2 & 2 & 65 & 2003 & Private & 170 \\
\hline \multirow[t]{2}{*}{22} & Nagasar & - & 2 & 2 & 45 & 2004 & Private & 60 \\
\hline & Total & & & 35 units & $\begin{aligned} & 1058 \mathrm{~kW} \\
= & 1.058 \mathrm{MW}\end{aligned}$ & - & - & $\begin{array}{c}2160 \\
\text { Households }\end{array}$ \\
\hline
\end{tabular}

Source: Field Survey. 
Table 2

Financial Analysis of Cash Flow of MHP Plant

(In 000 Rs.)

\begin{tabular}{|c|c|c|c|c|c|c|}
\hline & Year & Initial Capital Cost & $\mathrm{O}$ and $\mathrm{M}$ Cost & Total Cost & Benefit of the Project & Net Benefit \\
\hline 0 & 2010 & 402 & 0 & 402 & 0 & -402 \\
\hline 1 & 2011 & 0 & 120 & 120 & 216 & 96 \\
\hline 2 & 2012 & 0 & 120 & 120 & 216 & 96 \\
\hline 3 & 2013 & 0 & 120 & 120 & 216 & 96 \\
\hline 4 & 2014 & 0 & 120 & 120 & 216 & 96 \\
\hline 5 & 2015 & 0 & 120 & 120 & 216 & 96 \\
\hline 6 & 2016 & 0 & 120 & 120 & 216 & 96 \\
\hline 7 & 2017 & 0 & 120 & 120 & 216 & 96 \\
\hline 8 & 2018 & 0 & 120 & 120 & 216 & 96 \\
\hline 9 & 2019 & 0 & 120 & 120 & 216 & 96 \\
\hline 10 & 2020 & 0 & 120 & 120 & 216 & 96 \\
\hline 11 & 2021 & 0 & 135 & 135 & 233 & 98 \\
\hline 12 & 2022 & 0 & 135 & 135 & 233 & 98 \\
\hline 13 & 2023 & 0 & 135 & 135 & 233 & 98 \\
\hline 14 & 2024 & 0 & 135 & 135 & 233 & 98 \\
\hline 15 & 2025 & 0 & 135 & 135 & 233 & 98 \\
\hline 16 & 2026 & 0 & 135 & 135 & 233 & 98 \\
\hline 17 & 2027 & 0 & 135 & 135 & 233 & 98 \\
\hline 18 & 2028 & 0 & 135 & 135 & 233 & 98 \\
\hline 19 & 2029 & 0 & 135 & 135 & 233 & 98 \\
\hline 20 & 2030 & 0 & 135 & 135 & 233 & 98 \\
\hline 21 & 2031 & 0 & 135 & 135 & 233 & 98 \\
\hline 22 & 2032 & 0 & 135 & 135 & 233 & 98 \\
\hline 23 & 2033 & 0 & 135 & 135 & 233 & 98 \\
\hline 24 & 2034 & 0 & 135 & 135 & 233 & 98 \\
\hline 25 & 2035 & 0 & 135 & 135 & 233 & 98 \\
\hline \multicolumn{7}{|c|}{$\begin{array}{ll}\text { Net Present Value } & 350.01 \\
\text { Benefit Cost Ratio } & 1.25 \\
\text { Internal Rate of Return } 24 \text { percent } \\
\text { Payback Period } \quad 5 \text { Years }\end{array}$} \\
\hline
\end{tabular}


Table 3

Economic Analysis of Cash Flow of MHP

\begin{tabular}{|c|c|c|c|c|c|c|c|}
\hline & Year & $\begin{array}{c}\text { Initial Capi } \\
\text { Cost }\end{array}$ & & $\begin{array}{c}\mathrm{O} \text { and } \mathrm{M} \\
\text { Cost }\end{array}$ & $\begin{array}{l}\text { Total } \\
\text { Cost }\end{array}$ & $\begin{array}{l}\text { Benefit of the } \\
\text { Project }\end{array}$ & $\begin{array}{c}\text { Net } \\
\text { Benefit }\end{array}$ \\
\hline 0 & 2010 & 396.18 & & $\overline{0}$ & 396.18 & 0 & -396.18 \\
\hline 1 & 2011 & 0 & & 108 & 108 & 216 & 108 \\
\hline 2 & 2012 & 0 & & 108 & 108 & 216 & 108 \\
\hline 3 & 2013 & 0 & & 108 & 108 & 216 & 108 \\
\hline 4 & 2014 & 0 & & 108 & 108 & 216 & 108 \\
\hline 5 & 2015 & 0 & & 108 & 108 & 216 & 108 \\
\hline 6 & 2016 & 0 & & 108 & 108 & 216 & 108 \\
\hline 7 & 2017 & 0 & & 108 & 108 & 216 & 108 \\
\hline 8 & 2018 & 0 & & 108 & 108 & 216 & 108 \\
\hline 9 & 2019 & 0 & & 108 & 108 & 216 & 108 \\
\hline 10 & 2020 & 0 & & 108 & 108 & 216 & 108 \\
\hline 11 & 2021 & 0 & & 121 & 121 & 233 & 111 \\
\hline 12 & 2022 & 0 & & 121 & 121 & 233 & 111 \\
\hline 13 & 2023 & 0 & & 121 & 121 & 233 & 111 \\
\hline 14 & 2024 & 0 & & 121 & 121 & 233 & 111 \\
\hline 15 & 2025 & 0 & & 121 & 121 & 233 & 111 \\
\hline 16 & 2026 & 0 & & 121 & 121 & 233 & 111 \\
\hline 17 & 2027 & 0 & & 121 & 121 & 233 & 111 \\
\hline 18 & 2028 & 0 & & 121 & 121 & 233 & 111 \\
\hline 19 & 2029 & 0 & & 121 & 121 & 233 & 111 \\
\hline 20 & 2030 & 0 & & 121 & 121 & 233 & 111 \\
\hline 21 & 2031 & 0 & & 121 & 121 & 233 & 111 \\
\hline 22 & 2032 & 0 & & 121 & 121 & 233 & 111 \\
\hline 23 & 2033 & 0 & & 121 & 121 & 233 & 111 \\
\hline 24 & 2034 & 0 & & 121 & 121 & 233 & 111 \\
\hline 25 & 2035 & 0 & & 121 & 121 & 233 & 111 \\
\hline \multicolumn{3}{|c|}{ Net Present Value } & \multicolumn{5}{|c|}{459.16} \\
\hline \multicolumn{3}{|c|}{ Benefit Cost Ratio } & \multicolumn{5}{|c|}{1.36} \\
\hline \multicolumn{3}{|c|}{ Inter Rate of Return } & \multicolumn{5}{|c|}{27 percent } \\
\hline & \multicolumn{2}{|c|}{ Payback Period } & \multicolumn{3}{|c|}{ 3.6 Years } & & \\
\hline
\end{tabular}


Table 4

Sensitivity Analysis of Cash Flow of MHP

\begin{tabular}{|c|c|c|c|c|c|c|}
\hline & Year & $\begin{array}{c}\text { Initial Capital Cost } \\
\text { of the Project }\end{array}$ & $\begin{array}{c}0 \text { and } \mathrm{M} \\
\text { Cost }\end{array}$ & $\begin{array}{l}\text { Total } \\
\text { Cost }\end{array}$ & $\begin{array}{l}\text { Benefit of } \\
\text { the Project }\end{array}$ & $\begin{array}{c}\text { Net } \\
\text { Benefit }\end{array}$ \\
\hline 0 & 2010 & 440.2 & 0 & 440.2 & 0 & -440.2 \\
\hline 1 & 2011 & 0 & 120 & 120 & 216 & 96 \\
\hline 2 & 2012 & 0 & 120 & 120 & 216 & 96 \\
\hline 3 & 2013 & 0 & 120 & 120 & 216 & 96 \\
\hline 4 & 2014 & 0 & 120 & 120 & 216 & 96 \\
\hline 5 & 2015 & 0 & 120 & 120 & 216 & 96 \\
\hline 6 & 2016 & 0 & 120 & 120 & 216 & 96 \\
\hline 7 & 2017 & 0 & 120 & 120 & 216 & 96 \\
\hline 8 & 2018 & 0 & 120 & 120 & 216 & 96 \\
\hline 9 & 2019 & 0 & 120 & 120 & 216 & 96 \\
\hline 10 & 2020 & 0 & 120 & 120 & 216 & 96 \\
\hline 11 & 2021 & 0 & 135 & 135 & 233 & 98 \\
\hline 12 & 2022 & 0 & 135 & 135 & 233 & 98 \\
\hline 13 & 2023 & 0 & 135 & 135 & 233 & 98 \\
\hline 14 & 2024 & 0 & 135 & 135 & 233 & 98 \\
\hline 15 & 2025 & 0 & 135 & 135 & 233 & 98 \\
\hline 16 & 2026 & 0 & 135 & 135 & 233 & 98 \\
\hline 17 & 2027 & 0 & 135 & 135 & 233 & 98 \\
\hline 18 & 2028 & 0 & 135 & 135 & 233 & 98 \\
\hline 19 & 2029 & 0 & 135 & 135 & 233 & 98 \\
\hline 20 & 2030 & 0 & 135 & 135 & 233 & 98 \\
\hline 21 & 2031 & 0 & 135 & 135 & 233 & 98 \\
\hline 22 & 2032 & 0 & 135 & 135 & 233 & 98 \\
\hline 23 & 2033 & 0 & 135 & 135 & 233 & 98 \\
\hline 24 & 2034 & 0 & 135 & 135 & 233 & 98 \\
\hline 25 & 2035 & 0 & 135 & 135 & 233 & 98 \\
\hline IRR & & $22 \%$ & & & & \\
\hline NPV & & 317.7 & & & & \\
\hline BCR & & 1.22 & & & & \\
\hline PBP & & 5.5 years & & & & \\
\hline
\end{tabular}


Table 5

\section{Main Issues Identified through Informal Survey Techniques} (Focused Group Discussion and Key Informant Survey)

\begin{tabular}{|c|c|c|c|c|}
\hline S \# & Issues & Evidence & Causes & Solution \\
\hline$\overline{1}$ & Unskilled operators & $\begin{array}{l}70 \% \text { of the operators of } \\
\text { MHP plants are illiterate }\end{array}$ & $\begin{array}{l}\text { Poverty and low } \\
\text { education facilities }\end{array}$ & $\begin{array}{l}\text { Impart technical trainings } \\
\text { to the operators for the } \\
\text { successful operation of } \\
\text { plants }\end{array}$ \\
\hline 2 & Financial constraints & $\begin{array}{l}\text { The electro mechanical } \\
\text { equipments and civil works } \\
\text { are not in accordance with } \\
\text { proper specification and } \\
\text { standards (personal } \\
\text { observations). }\end{array}$ & $\begin{array}{l}\text { Low income level of the } \\
\text { people and lack of } \\
\text { financing facilities. } \\
\text { They cannot afford the } \\
\text { expensive civil works } \\
\text { for flood control. }\end{array}$ & $\begin{array}{l}\text { Proper commercialisation } \\
\text { of the technology and loans } \\
\text { should be given to } \\
\text { encourage the technology }\end{array}$ \\
\hline 3 & $\begin{array}{l}\text { Risk of electric } \\
\text { shocks }\end{array}$ & $\begin{array}{l}3 \text { to } 4 \text { children have been } \\
\text { electrocuted in the past } \\
\text { according to the information } \\
\text { shared by the community } \\
\text { members. }\end{array}$ & $\begin{array}{l}\text { Majority of the poles } \\
\text { that supply electricity } \\
\text { from power plants to the } \\
\text { houses are wooden. } \\
\text { These poles often fall } \\
\text { during rain, snow fall or } \\
\text { cyclones and pose a risk } \\
\text { to human lives. }\end{array}$ & $\begin{array}{l}\text { Installation of steel or iron } \\
\text { poles with proper } \\
\text { transmission lines to the } \\
\text { houses. }\end{array}$ \\
\hline 4 & $\begin{array}{l}\text { Disputes on site } \\
\text { selection }\end{array}$ & $\begin{array}{l}\text { Community members of two } \\
\text { villages have a dispute on } \\
\text { site selection of MHP } \\
\text { project. As a result of this } \\
\text { dispute about } 12 \text { electric } \\
\text { poles were stolen by the } \\
\text { members of another village } \\
\text { and later on recovered. }\end{array}$ & $\begin{array}{l}\text { Political interference } \\
\text { from the local political } \\
\text { figures for the selection } \\
\text { of site for government } \\
\text { project. }\end{array}$ & $\begin{array}{l}\text { There should be an } \\
\text { independent body for } \\
\text { selection of sites and } \\
\text { execution of project in } \\
\text { view of the transparency } \\
\text { and need of the local } \\
\text { population. }\end{array}$ \\
\hline 5 & $\begin{array}{l}\text { Demand for more } \\
\text { MHP connections }\end{array}$ & $\begin{array}{l}\text { About } 50 \text { percent of } \\
\text { households in those villages } \\
\text { are without MHP electricity. }\end{array}$ & $\begin{array}{l}\text { Low installed capacity } \\
\text { ranging from } 10 \mathrm{Kw} \text { up } \\
\text { to } 50 \mathrm{Kw}\end{array}$ & $\begin{array}{l}\text { At least it should be } \geq 100 \\
\text { Kw. }\end{array}$ \\
\hline 6 & $\begin{array}{l}\text { Non- cooperation of } \\
\text { community } \\
\text { members }\end{array}$ & $\begin{array}{l}\text { They misuse electricity of } \\
\text { the plant by using heaters } \\
\text { etc. leading to the break } \\
\text { down MHP plant. }\end{array}$ & $\begin{array}{l}\text { Flat tariff charged from } \\
\text { the consumers } \\
\text { irrespective of the level } \\
\text { of consumption. }\end{array}$ & $\begin{array}{l}\text { Tariffs should be charged } \\
\text { according to the } \\
\text { consumption of electricity, } \\
\text { household size and income } \\
\text { level. The village } \\
\text { committee should be } \\
\text { empowered to tackle the } \\
\text { issue of maintenance, } \\
\text { repairing and collection of } \\
\text { bills. }\end{array}$ \\
\hline 7 & $\begin{array}{l}\text { Fusing of electric } \\
\text { generator in thunder } \\
\text { storms }\end{array}$ & $\begin{array}{l}\text { Information about these } \\
\text { cases was provided by the } \\
\text { respondents. }\end{array}$ & $\begin{array}{l}\text { No transformer is } \\
\text { installed. }\end{array}$ & $\begin{array}{l}\text { Proper installation of step } \\
\text { down transformer should } \\
\text { be ensured to avoid fusing } \\
\text { of lights and other } \\
\text { appliances owing to higher } \\
\text { voltage. }\end{array}$ \\
\hline 8 & Lack of awareness & $\begin{array}{l}\text { Misuse of electricity in } \\
\text { different forms. }\end{array}$ & $\begin{array}{l}\text { The community } \\
\text { members consider the } \\
\text { project as a public or } \\
\text { free good. }\end{array}$ & $\begin{array}{l}\text { Awareness workshops } \\
\text { should be arranged for the } \\
\text { local people and operators } \\
\text { so that they can get the } \\
\text { required skills. }\end{array}$ \\
\hline
\end{tabular}




\section{REFERENCES}

Ahmad, A. and A. Salman (2012) Clean Development Mechanism (CDM) Business in Pakistan: Perceptions and Realities. Pakistan Institute of Development Economics, Islamabad.

Akella, A., R. Saini, and M. Sharma (2009) Social, Economical and Environmental Impacts of Renewable Energy Systems. Renewable Energy 34:2, 390-396.

Condrea, P., and I. Bostan (2008) Environmental Issues from an Economic Perspective. Environmental Engineering and Management Journal 7:6, 843-849.

Dolf, G. (2012) Renewable Energy: Cost Analysis Series. IRENA Working Paper 1(3/5).

Dorji, K. (2007) The Sustainable Management of Micro Hydropower Systems for Rural Electrification: The Case of Bhutan. Humboldt State University.

Edvard (2011) Economic Analysis of an MHPP. Electrical Engineering Portal.

Greenstone, M. (2014) Energy, Growth and Development. Oxford University, UK: International Growth Centre.

Hanggoro (1998) The Economic Analysis of Mini/ Micro Hydro Power Plant in Indonesia. Thailand.

IESCO (2013) Scedule of Electricity Tariff for Islamabad Electric Supply Company (IESCO). Islamabad.

Khennas, S. and A. Barnett (2000) Best Practices for Sustainable Dvelopment of Micro Hydro Power in Developing Countries.: Department for International Development, UK.

Kumar, K. (1989) Conducting Key Informant Interviews in Developing Countries: Agency for International Development. Washington, DC.

Mirza, U. K., N. Ahmad, K. Harijan, and T. Majeed (2009) Identifying and Addressing Barriers to Renewable Energy Development in Pakistan. Renewable and Sustainable Energy Reviews 13:4, 927-931.

Nizami, A., and N. Bukhari (2010) Hands-on Capacity Building of Forest Officials on Making Project Design Documents for Clean Development Mechanism. Islamabad, Pakistan.

Paish, O. (2002) Micro-hydropower: Status and Prospects. Proceedings of the Institution of Mechanical Engineers, Part A: Journal of Power and Energy 216:1, 31-40.

Pakistan, Government of (2013) National Power Policy 2013. Pakistan.

Pandey, B. (2008) Community-Based Renewable Energy Development in the Northern Areas and Chitral, Pakistan. Clean Development Mechanism, Project Design Document.

Purohit, P. (2008) Small Hydro Power Projects under Clean Development Mechanism in India: A Preliminary Assessment. Energy Policy 36:6, 2000-2015.

Sarala, A. P. (2009) Economic Analysis and Application of Small Micro/Hydro Power Plants. Paper presented at the International Conference on Renewable Energies and Power Quality (ICREPQ'09), Valencia (Spain).

Shakya, S. R. (2005) Application of Renewable Energy Technology for Greenhouse Gas Emission Reduction in Nepalese Context: A Case Study. Nepalese Journal of Engineering 1:1, 92-101.

Sharon, C. and P. Angela (2012) Regulation of Emissions under the Carbon Pricing Mechanism: A Case Study of Australia's Coal Fired Electricity Sector. Asia Pacific Journal of Environmental Law 15, 17-50. 
Sheikh, M. A. (2010) Energy and Renewable Energy Scenario of Pakistan. Renewable and Sustainable Energy Reviews 14:1, 354-363.

UNFCCC (nd). UNFCCC, Parties and Oservers. Retrieved 21 November, 2014.

Woodruff, A. (2007a) An Economic Assessment of Renewable Energy Options for Rural Electrification in Pacific Island Countries: SOMAC.

Woodruff, A. (2007b) An Economic Assessment of Renewable Energy Options for Rural Electrification in Pacific Island Countries (AusAID, Trans.). Australia: SOPAC. 


\section{Comments}

It is a distinctive paper that uses the informal techniques for the analysis and truly unravels the hidden, firsthand information on the sustainable electricity generation in rural communities in Pakistan. This paper shares important information and provides the economic assessment on the feasibility of micro-hydro power generation. However, I would like to float few suggestions that I guess will help to further improve this work.

(1) The write up needs a serious effort to improve the text. There are small paragraphs and the paper lacks in logical buildup of arguments.

(2) The authors seems to be biased towards MHPs and therefore puts extra effort to support the already obvious economically viable solution i.e. micro-hydro power (MHP) plants.

(3) There is a lot of material that is redundant in terms of an academic paper like details of cost-benefit techniques. Such information needs to be attached only as appendix if so necessary.

(4) Tables sometimes makes the reader confused and authors should spare some time to make them presentable and easy to comprehend.

(5) Repetition and irrelevant terms like names of statistical packages (SPSS, Excel) should be removed from the text.

(6) The authors should only report the economic feasibility of MHP projects. Economic feasibility is more meaningful than that of financial feasibility. This will be more efficient in terms of time and space and for keeping the reader's interest intact.

(7) Furthermore, it seems that authors have used hypothetical figures for costs and benefit flows related to MHP plants (at Tables 4.9 and 4.10). This is undesirable as we can see at appendix-A that there are plants operating as far as from 2003, therefore, it would be more meaningful to use actual cost and benefits figures where available.

(8) The most remarkable contribution of this work to me is the calculation of revenue potential that Pakistan can benefit from via trade at carbon markets through Clean Development Mechanism and the authors should be praised for it.

(9) Lastly, I would recommend that the paper should be concluded following section 4.5.3. The rest of the material (i.e. issues and findings from Focus Group Discussion) should either be removed from this paper or can be attached as appendix, if authors think these so important. This will help to keep the attention of the reader intact and to properly conclude following the chronological progression of the paper.

Last but not the least, this is a nice attempt and reflects the hard work done by the authors. The findings are expected to help the policy makers to find a solution to such an important need of Pakistan at this time i.e. efficient electricity generation.

Pakistan Institute of Development Economics,

Iftikhar Ahmad Islamabad. 